\title{
Effects of Intercropping Sunflower with Sugar Beet under Different Plant Densities and Defoliation Levels on Yield and Production Efficiency of Both Crops
}

\author{
Wafaa Kh. Mohammed and Abd El Zaher, Sh. R., \\ Crop Intensification Res. Dept. Field Crops Res. Inst., A.R.C., Giza, Egypt.
}

\begin{abstract}
Two field trials were carried out in Agriculture Research Station, Giza, Egypt during 2009/2010 and 2010/2011 seasons to study the effect of intercropping sugar beet with different plant densities of sunflower $(100 \%, 80 \%$ and $67 \%$ sunflower plants from pure stand) and four defoliation levels of sunflower plants $(75,50$, $25 \%$ and $0 \%$ at milk ripe stage) on growth, yield and yield components of sunflower (Helianthus annus L.) and sugar beet (Beta vulgaris L.).

Sugar beet (c.v. Kawemire), as the main crop, was seeded in hills spaced $20 \mathrm{~cm}$ on two sides of wide ridges $120 \mathrm{~cm}$ apart, both in intercropping and monoculture patterns to achieve full stand of 35000-plants/ fed. Sunflower (c.v. Giza 102) as a sole crop was seeded in hills spaced $20 \mathrm{~cm}$ apart and one plant per hill on both sides of the ridges $120 \mathrm{~cm}$ to achieve full stand 35,000 plants/fed. Intercropped sunflower was sown at one plant per hill spaced 20, 25 and $30 \mathrm{~cm}$ on two rows in the top of ridges $120 \mathrm{~cm}$ width. The experiments included 12 treatments, in addition to monocultures of sunflower and sugar beet as checks. The experiments were designed a Randomized Complete Block Design (RCBD) with three replications.
\end{abstract}

\section{The obtained results indicated that}

1- Intercropping pattern of $100 \%$ sugar beet $+67 \%$ sunflower of plant density and $75 \%$ defoliated leaves gave the highest yield of root and sugar fed. ${ }^{-1}$, while intercropping $100 \%$ sugar beet $+100 \%$ sunflower of plant density and without defoliated leaves gave the lowest yield of root and sugar per fed., as compared with yield of monoculture sugar beet in two seasons.

2- Intercropping pattern of $100 \%$ sugar beet $+100 \%$ sunflower of plant density and without defoliated leaves gave the highest seed yield of sunflower fed. ${ }^{-1}$, while intercropping $100 \%$ sugar beet $+67 \%$ sunflower of plant density and $75 \%$ defoliated leaves gave the lowest seed yield of sunflower per fed., as compared with yield of monoculture sunflower in two seasons.

3- Highest value of Land Equivalent Ratio (LER) and Area Time Equivalent ratio (ATER), 1.51 and 1.17 were recorded with $100 \%$ sugar beet $+80 \%$ sunflower of plant density and $50 \%$ defoliating of sunflower leaves over the two seasons . This treatment gave also highest income L.E 8729 fed. $^{-1}$ as average of both seasons.

Key words: intercropping, sugar beet, sunflower, defoliation, growth, yield, Production efficiency, LER.

\section{Introduction}

Sugar beet is an important sugar crop in the world and ranks next to sugar cane as a source of sugar in Egypt, also sunflower is one of the most important oil crops occupying the fourth place in the world. In Egypt, the area devoted to sunflower in the crop structure is very limited. Therefore, increasing the cropped area of oil seed crops is an important target to reduce the gab between our production and consumption from edible oils. Intercropping can be used, as one of the most effective methods to increase the area of oil crops, intercropping can be considered an effective method.

Toaima et al (2001) found that intercropping sugar beet with onion and garlic resulted in greater yield, yield components and improved quality of sugar beet. The highest values of LER were obtained when 16 plants/ $\mathrm{m}^{2}$ of faba bean were intercropped on sugar beet, but the highest yield of sugar beet was obtained from intercropping five faba bean plants $/ \mathrm{m}^{2}$ (Abd El-All, 2002). Beshay et al, (2000) reported that the reduction in sugar beet productivity was due not only to intercropping but also to intercropped density. Also intercropping increased markedly farmer net and profitability per unit capital input (one LE). Mohammed et al, (2005) indicated that growth, yield, and yield components of sugar beet were significantly decreased by the intercropping with faba bean as compared with solid sugar beet. Sugar beet yield and its attributes were significantly reduced with increasing plant density of the companion crop. The maximum values of LER, and $\mathrm{K}$ were obtained when $100 \%$ sugar beet was intercropped with $33 \%$ faba bean.

Nagangoud and Yelshetty (1996) stated that seed yield of sunflower generally decreased by defoliation at 50 days after sowing. Abbaspour et al, (2001) indicated that plant height, stem diameter, head diameter, harvest index and grain yield of sunflower were decreased as a result of partial or complete leaf excision of sunflower plant when 
compared with the undefoliated control (kept unremoval). Muro et al, (2001) stated that sunflower yield loss increased with increasing level of defoliation. Moriondo et al, (2002) reported that the yield of sunflower plants defoliated during preanthesis caused high yield loss. Sunflower was observed to be fairly tolerant of competition with maize (Olanite et al, 2002). Beg et al, (2003) found that increasing populations of sunflower, from 80,000 to 100,000 plants /ha significantly produced high yields. The seed yield of sunflower was reduced under intercropping system sunflower - peanut (Arachis hipogaea L.) (Sahoo et al, 2003). Mohammed (2006) found that sunflower yield was maximized with no defoliation and followed by $25 \%$ leaf defoliation, while the lowest seed yield was obtained when $75 \%$ of leaves were defoliated. The highest values of land equivalent ratio and total income were recorded at $25 \%$ defoliation of sunflower leaves at milky ripe stage. El Yamani et al, (2010) studied two defoliation levels (50 and $75 \%$ ) of sunflower intercropped with soybean, and found that the highest sunflower yield was obtained from pure stand with no leaf defoliation, whereas the lowest value was obtained when sunflower was intercropped with soybean with $75 \%$ leaf defoliation. In addition LER was increased. Osman and Awed (2010) indicated that the highest plant height was obtained from narrow spacing between plants of sunflower $(10 \mathrm{~cm})$. The highest stem and head diameter, seed husk, and seed yield per plant of sunflower were recorded at wide spacing $(30 \mathrm{~cm})$. Intercropping not only helps to solve the problem of pulses and oilseed production but also helps to bring additional income to farmers. Besides to get higher benefits with lower cost of cultivation and helps to utilize the growth resources and the time (duration) very efficiently and numerically the land usage can be intensified (Vishwanatha et al, 2011).

Little information is available about intercropping sunflower and sugar beet. Among the agronomic practices, optimum plant population plays a major role. The aim of these experiments was to test sunflower as companion crop in association with sugar beet under different plant densities and some sunflower defoliation treatments for high yields of the two crops.

\section{Materials and Methods}

Two field trials was conducted in 2009/2010 and 2010/2011 growing seasons in the experimental Research station of the Agriculture Research Center, Giza, Egypt. The trials were conducted to determine the effect of intercropping sunflower (Helianthus annus L.) with sugar beet (Beta vulgaris L.). Trials were arranged as Randomized Complete Block Design (RCBD) in three replications. Combinations of Three plant density (100\%, 80\% and 67\%) of sunflower plants from pure stand were used. The ratios of intercropped sunflower differed according to hill spacing as follows, $20 \mathrm{~cm}$ between hills $(100 \%), 25 \mathrm{~cm}$ between hills $(80 \%)$ and $30 \mathrm{~cm}$ between hills $(67 \%)$, and four defoliation levels $(75$, $50,25 \%$ and $0 \%$ ) of sunflower plants at milk ripe stage were devoted, after 53and 58 days from planting time in the first and second seasons, respectively. in addition to monocultures of sugar beet and sunflower were sown as checks. Sugar beet, as the main crop, was seeded one plant in hills spaced $20 \mathrm{~cm}$ on two sides of wide ridges, $120 \mathrm{~cm}$ apart, both in intercropping and monoculture patterns to achieve full stand of 35,000-plants/ fed. Sunflower (c.v. Giza 102) as a sole crop, was seeded in hills spaced $20 \mathrm{~cm}$ apart and one plant per hill on both sides of the ridge, $120 \mathrm{~cm}$ to achieve full stand 35,000 plants/fed and on the two rows on the top of bedes in all intercropping patterns Sunflower was sown with three seeds in each hill, and the plots were hand-thinned to one plant per hill spaced 20, 25 and $30 \mathrm{~cm}$ when the plants were at the 4 to 6-leaf stage on two rows on the top of ridge.

Sugar beet (C.V. Kawemire) either in pure or intercropped was sown on $20^{\text {th }}$ and $15^{\text {th }}$ of October in 2009 and 2010 seasons, respectively. Sunflower plants were sown on $20^{\text {th }}$ and $15^{\text {th }}$ in November either in pure or intercropped sowing in the first and second seasons, respectively. Weeds in the rows were removed by hand. The preceding crop was maize (Zea mays L.). The chemical and mechanical analysis of the experimental soil is presented in Table 1 was done by Water and Soil Research Institute, A.R.C. using the methods described by Jackson (1958) and Chapman and Pratt (1961).

Table 1. Chemical and mechanical analysis of the experimental soil.

\begin{tabular}{ccccccccc}
\hline Soil depth & \multicolumn{3}{c}{ Chemical analysis } & \multicolumn{3}{c}{ Mechanical and analysis } \\
\cline { 2 - 8 }$(\mathrm{cm})$ & $\mathrm{EC}\left(\mathrm{Ds} \mathrm{m}^{-1}\right)$ & PH & Organic & Total N \% & Sand \% & Silt \% & Clay \% & Texture \\
$0-30$ & 0.85 & 7.47 & 1.45 & 1.58 & 26.51 & 1.73 & 71.76 & Clay loam \\
\hline
\end{tabular}

Calcium super phosphate $\left(\begin{array}{lll}15 \% & \mathrm{P}_{2} \mathrm{O}_{5}\end{array}\right)$ was added during seedbed preparation at a rate of $150 \mathrm{~kg}$ $\mathrm{fed}^{-1}$. Nitrogen fertilizer was added at the rate of 150 $\mathrm{kg} \mathrm{N}$ fed. ${ }^{-1}$ in two equal doses in form of ammonium nitrate $(33 \% \mathrm{~N})$ was add at 30 and 45 days from sowing date of sugar beet. Potassium fertilizer was added in form of potassium sulphate $\left(48 \% \mathrm{~K}_{2} \mathrm{O}\right)$ at rate of $150 \mathrm{~kg} \mathrm{fed}^{-1}$ after 45 days from sowing. The other cultural practices were applied for both crops, as recommended. The area of plot was $43.2 \mathrm{~m}^{2}$ consisting of 6 ridges, each of $6.0 \mathrm{~m}$ in length and $1.2 \mathrm{~m}$ in width. 
The following characters were studied: 1- Sugar beet:

At 180 days after sowing, sugar beet plants grown on the four inner ridges $4 \mathrm{~m}$ long and $1.2 \mathrm{~m}$ width $\left(19.2 \mathrm{~m}^{2}\right)$ of each plot were pulled, topped and counted. Fresh weight and yield of root and top per plant and per fed. were calculated. Root length and diameter were recorded on a random sample of 10 roots. Sucrose percentage was polar metrically determined on a lead acetate extract of fresh macerated root according to the method of Le- Docte (1927). Sugar yield fed. ${ }^{-1}$ was calculated by multiplying root yield/fed by root sucrose percentage.

\section{2-Sunflower:}

Sunflower was harvested 95days after sowing (55days before sugar beet harvest). Plant height, leaf area, stem diameter, head diameter and weight of seeds /head were studied. These characters were recorded from the average of five guarded plants from each plot. At maturity, head samples for yield were harvested from the central four ridges, $4 \mathrm{~m}$ long and $1.2 \mathrm{~m}$ width $\left(19.2 \mathrm{~m}^{2}\right)$ of each plot and converted to yield fed.-1 seed yield was adjusted to a $10.0 \%$ moisture basis.

\section{3-Competitive relationships:}

\section{Land equivalent ratio (LER):}

LER is the ratio of area needed under sole cropping to that of intercropping at the same management level to produce an equivalent yield according to Willey (1979). It was calculated as follows:

$$
\mathrm{LER}=\mathrm{Yab} / \mathrm{Yaa}+\mathrm{Yba} / \mathrm{Ybb}
$$

Where: Yaa and Ybb are the sole crop yields of sugar beet (a) and sunflower (b), respectively. Yab is the intercrop yield of sugar beet (a) when combined with sunflower (b) and Yba is the intercrop yield of sunflower (b) when combined with sugar beet yield (a). LER values may be less, equal or more than 1.0 which, indicate the disadvantage, noadvantage and advantage of the intercropping system, respectively.

\section{Area Time Equivalent Ratio (ATER):}

Area time equivalent ratio provides a comparison of the yield advantage of intercropping over monocropping in terms of time taken by component crops in the intercropping systems according to (Hiebsch 1980). ATER was calculated by formula Area time equivalent ratio

$$
\mathrm{ATER}=\left(\mathrm{LER}_{\text {sugar beet }} \mathrm{x} \mathrm{Dc}+\mathrm{LER}_{\text {sunflower }} \mathrm{x}\right.
$$

Where LER is land equivalent ratio of crop, Dc is duration (days) taken by crop, Dt is days taken by whole intercropping system from planting to harvest.

\section{4- Economic evaluation}

The total return per feddan from each treatment was calculated in Egyptian pound at market price. The average market price was LE 2750 ton $^{-1}$ for sunflower seeds and LE 263 ton $^{-1}$ for fresh sugar beet roots, as an average of the two seasons. The average of sugar beet and sunflower yield price presented by Agricultural Statistics (2010 and 2011) was used.

Statistical analysis of the collected data was done using MSTATC (1980) software with means comparison by least significant difference test (LSD) using 5\% probability levels according to Snedecor and Cochran (1988).

\section{Results and Discussion}

\section{A- Growth and yield of sugar beet:}

Results presented in Table (2) indicated that all characters of intercropped sugar beet were significantly decreased by intercropping sunflower at different plant densities and defoliation as compared with sugar beet monoculture except sucrose \%, in both seasons. In comparison among the intercropping treatments, it was found that intercropping sunflower at $67 \%$ of its plant density and at $75 \%$ defoliation of its leaves with sugar beet gave the highest values of length, diameter, fresh weight, top fresh weight, yield of roots and sugar ton fed. $^{-1}$, while the lowest values were recorded by intercropping sunflower at $100 \%$ of its plant density without leaf defoliation except of sucrose $\%$ not significant, in both seasons.

Such results are mainly due to the effect of both intra and inter competition between sugar beet and sunflower plants. Sugar beet plants were shaded by sunflower especially at high sunflower density and low defoliation level, which decreased sugar beet growth traits compared with solid culture. In this concern, Abd El-All, (2002) and Mohammed et al, (2005) reported similar results in the intercropping of sugar beet with faba bean.

Dc) $/ \mathrm{Dt}$ 
Table 2: Effects of intercropping sugar beet with sunflower at different plant densities and defoliation levels on growth, yield and yield components and sucrose $\%$ of sugar beet during 2009/2010 and 2010/2011seasons.

\begin{tabular}{|c|c|c|c|c|c|c|c|c|}
\hline \multirow{3}{*}{$\begin{array}{l}\text { Intercropping } \\
\text { system }\end{array}$} & \multirow{3}{*}{$\begin{array}{c}\text { Sunflower } \\
\text { defoliation } \\
\text { levels }\end{array}$} & \multicolumn{3}{|c|}{ Root plant $^{-1}$} & \multirow{2}{*}{$\begin{array}{l}\text { Top } \\
\text { fresh } \\
\text { weight }\end{array}$} & \multicolumn{2}{|c|}{ Yield fed. $^{-1}$ ton } & \multirow{2}{*}{$\begin{array}{c}\text { Sucrose } \\
\%\end{array}$} \\
\hline & & $\begin{array}{c}\text { Length } \\
(\mathrm{cm})\end{array}$ & $\begin{array}{c}\text { Diamet } \\
\text { er }\end{array}$ & $\begin{array}{c}\text { Fresh } \\
\text { weight }\end{array}$ & & Roots & Sugar & \\
\hline & & \multicolumn{7}{|c|}{ 2009/2010 season } \\
\hline \multirow{4}{*}{$\begin{array}{l}\text { Sugar beet } 100 \% \\
+100 \% \text { Sunflow }\end{array}$} & $0 \%$ & 18.30 & 9.23 & 493.3 & 215.3 & 12.53 & 2.12 & 16.94 \\
\hline & $25 \%$ & 20.33 & 9.50 & 537.7 & 283.0 & 15.50 & 2.61 & 16.84 \\
\hline & $50 \%$ & 23.00 & 10.27 & 599.0 & 283.7 & 21.10 & 3.51 & 16.63 \\
\hline & $75 \%$ & 23.33 & 11.27 & 615.0 & 310.7 & 23.33 & 3.88 & 16.63 \\
\hline \multirow{4}{*}{$\begin{array}{l}\text { Sugar beet } 100 \% \\
+80 \% \\
\text { Sunflower }\end{array}$} & $0 \%$ & 20.00 & 9.33 & 495.0 & 225.0 & 14.50 & 2.43 & 16.73 \\
\hline & $25 \%$ & 21.00 & 9.27 & 568.3 & 290.0 & 17.10 & 2.83 & 16.53 \\
\hline & $50 \%$ & 22.33 & 10.77 & 589.0 & 315.3 & 24.07 & 3.95 & 16.43 \\
\hline & $75 \%$ & 23.33 & 11.27 & 615.0 & 353.3 & 23.97 & 3.92 & 16.30 \\
\hline \multirow{4}{*}{$\begin{array}{l}\text { Sugar beet } 100 \% \\
+67 \% \\
\text { Sunflower }\end{array}$} & $0 \%$ & 23.67 & 9.57 & 553.7 & 241.3 & 15.47 & 2.57 & 16.63 \\
\hline & $25 \%$ & 24.33 & 10.20 & 593.3 & 270.3 & 18.43 & 3.02 & 16.40 \\
\hline & $50 \%$ & 24.33 & 11.00 & 643.7 & 322.7 & 23.37 & 3.76 & 16.07 \\
\hline & $75 \%$ & 25.00 & 12.50 & 761.0 & 371.7 & 25.00 & 3.93 & 15.73 \\
\hline \multicolumn{2}{|c|}{ Sugar beet $100 \%$ alone } & 25.33 & 12.87 & 783.7 & 374.4 & 30.45 & 4.90 & 16.1 \\
\hline \multicolumn{2}{|l|}{ LSD at $_{0.05}$} & 2.67 & 2.41 & 78.0 & 33.7 & 2.44 & 0.55 & $\mathrm{NS}$ \\
\hline \multirow{5}{*}{$\begin{array}{l}\text { Sugar beet } 100 \% \\
+100 \% \text { Sunflow }\end{array}$} & & \multicolumn{7}{|c|}{$2010 / 2011$ season } \\
\hline & $0 \%$ & 17.03 & 8.43 & 473.3 & 206.3 & 12.59 & 2.05 & 16.30 \\
\hline & $25 \%$ & 19.67 & 9.83 & 424.1 & 217.3 & 15.64 & 2.53 & 16.20 \\
\hline & $50 \%$ & 23.03 & 10.33 & 544.4 & 258.0 & 21.41 & 3.43 & 16.00 \\
\hline & $75 \%$ & 24.00 & 12.67 & 568.5 & 286.7 & 22.75 & 3.63 & 15.97 \\
\hline \multirow{4}{*}{$\begin{array}{l}\text { Sugar beet } 100 \% \\
+80 \% \\
\text { Sunflower }\end{array}$} & $0 \%$ & 17.97 & 9.40 & 456.7 & 213.3 & 14.63 & 2.35 & 16.10 \\
\hline & $25 \%$ & 20.73 & 9.33 & 425.3 & 229.0 & 18.69 & 2.95 & 15.80 \\
\hline & $50 \%$ & 23.00 & 11.00 & 505.3 & 270.3 & 22.12 & 3.47 & 15.70 \\
\hline & $75 \%$ & 24.00 & 11.33 & 529.7 & 304.0 & 23.04 & 3.59 & 15.60 \\
\hline \multirow{4}{*}{$\begin{array}{l}\text { Sugar beet } 100 \% \\
+67 \% \\
\text { Sunflower }\end{array}$} & $0 \%$ & 19.73 & 9.40 & 466.7 & 203.0 & 14.97 & 2.40 & 16.03 \\
\hline & $25 \%$ & 22.00 & 10.60 & 589.3 & 268.7 & 19.36 & 3.06 & 15.82 \\
\hline & $50 \%$ & 23.33 & 11.33 & 549.3 & 275.3 & 24.06 & 3.71 & 15.40 \\
\hline & $75 \%$ & 24.67 & 12.67 & 616.7 & 304.3 & 25.40 & 3.86 & 15.20 \\
\hline \multicolumn{2}{|c|}{ Sugar beet $100 \%$ alone } & 23.53 & 13.60 & 679.0 & 352.2 & 29.70 & 4.72 & 15.90 \\
\hline \multicolumn{2}{|l|}{ LSD at $_{0.05}$} & 2.58 & 2.26 & 75.2 & 25.2 & 2.54 & 0.56 & NS \\
\hline
\end{tabular}

2- Growth and yield of sunflower: -

Results presented in Table (3) indicated that all characters studied of intercropped sunflower, were significantly decreased by intercropping sunflower at different plant densities and leaf defoliation compared with sunflower monoculture except plant height, in both seasons. In comparison among the intercropping treatments, it was found that intercropping sunflower at $67 \%$ of its plant density with sugar beet without leaf defoliation gave the highest values of stem diameter, plant leaf area, head diameter and seed/ head, while the lowest values of these traits were recorded by intercropping sunflower at $100 \%$ of its plant density and $75 \%$ defoliation of its leaves in both seasons.

The response of seed yield fed. ${ }^{-1}$ of intercropped sunflower to plant densities and defoliation levels was different. The yield of seeds of sunflower was increased with increasing sunflower density up to $100 \%$ ( $20 \mathrm{~cm}$ between plants) without defoliation and the reduction in yield of sunflower was parallel to the decrease of sunflower plant density up to $75 \%$ with increasing level of defoliation. This trend may be due to increase of sunflower plants per unit area. Similar results in the intercropping sunflower - peanut (Arachis hipogaea L.) were recorded by Sahoo et al. (2003).

Maximum leaf area development is necessary for full interception and conversion of solar radiation

to efficient photosynthetic activity and carbohydrate accumulation in order to support maximum reproductive development and seed formation. In this concern, Abbaspour et al, 2001; Muro et al., 2001; Mohammed, 2006 and El-Yamni et al, 2010 reported similar conclusion. 
Table 3: Effect of intercropping sugar beet with sunflower at different plant densities and defoliation levels on growth, yield and yield components of sunflower plants during 2009/2010 and 2010/2011seasons.

\begin{tabular}{|c|c|c|c|c|c|c|c|}
\hline \multirow[t]{2}{*}{$\begin{array}{l}\text { Intercropping } \\
\text { system }\end{array}$} & \multirow{2}{*}{$\begin{array}{c}\text { Sunflower } \\
\text { defoliation } \\
\text { levels }\end{array}$} & $\begin{array}{l}\text { Plant height } \\
\text { (cm) }\end{array}$ & $\begin{array}{c}\text { Stem } \\
\text { diameter } \\
(\mathrm{cm})\end{array}$ & $\begin{array}{l}\text { Leave area } \\
\text { plant }\left(\mathrm{cm}^{2}\right)\end{array}$ & $\begin{array}{c}\text { Head } \\
\text { diameter } \\
(\mathrm{cm})\end{array}$ & $\begin{array}{l}\text { Seeds yield } \\
\operatorname{head}^{-1}(\mathrm{~g})\end{array}$ & $\begin{array}{l}\text { Seed yield } \\
\text { fed. }\left(\mathrm{kg}^{-1}\right)\end{array}$ \\
\hline & & \multicolumn{6}{|c|}{ 2009/2010 season } \\
\hline \multirow{4}{*}{$\begin{array}{l}\text { Sugar beet }+ \\
100 \% \text { Sunflower }\end{array}$} & $0 \%$ & 132.7 & 2.66 & 333.0 & 18.27 & 57.63 & 1103.0 \\
\hline & $25 \%$ & 129.0 & 2.59 & 319.7 & 17.20 & 53.33 & 1021.3 \\
\hline & $50 \%$ & 125.7 & 2.57 & 314.3 & 17.00 & 48.27 & 947.7 \\
\hline & $75 \%$ & 125.0 & 2.32 & 300.3 & 16.03 & 47.60 & 853.7 \\
\hline \multirow{5}{*}{$\begin{array}{l}\text { Sugar beet + } \\
80 \% \text { Sunflower }\end{array}$} & $0 \%$ & 135.7 & 2.95 & 371.3 & 18.40 & 63.10 & 901.7 \\
\hline & $25 \%$ & 134.3 & 2.91 & 343.3 & 17.43 & 54.67 & 865.7 \\
\hline & $50 \%$ & 131.3 & 2.60 & 334.7 & 16.67 & 50.47 & 853.3 \\
\hline & $75 \%$ & 127.7 & 2.55 & 339.0 & 16.47 & 48.17 & 753.0 \\
\hline & $0 \%$ & 143.0 & 3.14 & 406.7 & 19.27 & 68.00 & 853.3 \\
\hline \multirow{3}{*}{$\begin{array}{l}\text { Sugar beet + } \\
67 \% \text { Sunflower }\end{array}$} & $25 \%$ & 142.3 & 3.10 & 392.3 & 18.70 & 64.10 & 794.0 \\
\hline & $50 \%$ & 138.3 & 2.88 & 384.3 & 17.70 & 61.10 & 779.3 \\
\hline & $75 \%$ & 133.7 & 2.59 & 363.3 & 17.73 & 59.80 & 739.3 \\
\hline \multicolumn{2}{|c|}{ Sunflower $100 \%$ alone } & 139.1 & 3.24 & 391.2 & 20.90 & 63.77 & 1195.3 \\
\hline \multirow{2}{*}{\multicolumn{2}{|c|}{ LSD at 0.05}} & NS & 0.53 & 53.8 & 1.84 & 10.75 & 193.4 \\
\hline & & \multicolumn{6}{|c|}{ 2010/2011 season } \\
\hline \multirow{4}{*}{$\begin{array}{l}\text { Sugar beet }+ \\
100 \% \text { Sunflower }\end{array}$} & $0 \%$ & 132.7 & 2.40 & 334.7 & 17.70 & 58.70 & 1155.0 \\
\hline & $25 \%$ & 130.7 & 2.39 & 328.4 & 17.13 & 53.80 & 1079.7 \\
\hline & $50 \%$ & 129.0 & 2.36 & 314.3 & 16.47 & 53.00 & 983.0 \\
\hline & $75 \%$ & 127.3 & 2.22 & 306.3 & 15.70 & 50.10 & 893.3 \\
\hline \multirow{4}{*}{$\begin{array}{l}\text { Sugar beet }+ \\
80 \% \text { Sunflower }\end{array}$} & $0 \%$ & 136.0 & 2.82 & 362.0 & 18.37 & 63.10 & 964.7 \\
\hline & $25 \%$ & 136.7 & 2.74 & 351.0 & 18.30 & 56.23 & 931.3 \\
\hline & $50 \%$ & 137.7 & 2.68 & 350.3 & 17.27 & 56.00 & 894.0 \\
\hline & $75 \%$ & 135.3 & 2.66 & 342.7 & 16.80 & 53.90 & 832.0 \\
\hline \multirow{4}{*}{$\begin{array}{l}\text { Sugar beet }+ \\
67 \% \text { Sunflower }\end{array}$} & $0 \%$ & 144.7 & 2.97 & 398.7 & 19.27 & 67.37 & 890.3 \\
\hline & $25 \%$ & 146.0 & 2.95 & 390.7 & 18.43 & 63.57 & 845.0 \\
\hline & $50 \%$ & 142.7 & 2.67 & 373.7 & 18.27 & 61.90 & 845.7 \\
\hline & $75 \%$ & 141.0 & 2.54 & 372.7 & 17.67 & 59.97 & 783.3 \\
\hline \multicolumn{2}{|c|}{ Sunflower $100 \%$ alone } & 145.3 & 2.93 & 392.7 & 21.43 & 64.43 & 1236.7 \\
\hline \multicolumn{2}{|l|}{ LSD at 0.05} & $\mathrm{NS}$ & 0.43 & 39.4 & 2.59 & 10.30 & 192.0 \\
\hline
\end{tabular}

\section{C- Competitive relationships: -}

\section{1- Land equivalent ratio (LER)}

Results in Table (4) showed that the land equivalent ratio revealed the merits and demerits of intercropping system. All intercropping treatments of sunflower at plant density and different defoliation $\%$ with sugar beet recorded higher land equivalent ratio over sole cropping. Higher land equivalent ratio (1.51) averages of two seasons was obtained when sugar beet was intercropped with sunflower plant at $80 \%$ of the recommended plant density $(25 \mathrm{~cm}$ apart $)$ and $50 \%$ defoliation of sunflower leaves. Similar results were recorded by Sahoo et al, (2003), Mohammed (2006) and El Yamani et al, (2010).

\section{2- Area time equivalent ratio (ATER)}

Higher area time equivalent ratio (1.17) was obtained when sunflower was intercropped with sugar beet at $80 \%$ of the recommended plant density and $50 \%$ defoliation leaves of sunflower plants as averages of two seasons. These values indicated that intercropping system was highly efficient in utilizing the growth resources than sole cropping of both crops, (Table 4). Whereas, intercropping sunflower with sugar beet, at $67 \%$ of the recommended plant density $(25 \mathrm{~cm}$ apart) without defoliation leaves of sunflower, recorded the lowest values of ATER $(0.88)$ as an average of the two successive seasons. Similar results of higher LER and ATER were reported by several workers by Nagangound et al (1996), Olanite et al (2002) and Verma et al, (2005).

\section{D - Total economic:}

The data in Table (4) indicated that the highest value of total income (8729 L.E.) was recorded when sugar beet was intercropped with sunflower at $80 \%$ of the recommended plant density $(25 \mathrm{~cm}$ apart $)$ and 
at $50 \%$ of sunflower leaves defoliated, over the two seasons. However, the lowest value of total income (6397 and 6399 L.E.) were recorded when sugar beet was intercropped with sunflower at $80 \%$ or $67 \%$ of the recommended plant density $(25 \mathrm{~cm}$ and $30 \mathrm{~cm}$ apart) and without leaves defoliation of sunflower plants over both seasons. In the respect high return was reported when sunflower was intercropped with groundnut (over sole cropping) as reported by Patil et al. (2007).

Table 4. Productivity, land equivalent ratio (LER), area time equivalent ratio (ATER) and total economic of intercropped sugar beet and sunflower as influenced by some defoliation treatments and different plant density of sunflower plants (average of 2010 and 2011 seasons).

\begin{tabular}{|c|c|c|c|c|c|c|c|c|}
\hline \multirow{2}{*}{$\begin{array}{c}\text { Intercropping } \\
\text { system }\end{array}$} & \multirow{2}{*}{$\begin{array}{c}\text { Defoliation } \\
\text { level }\end{array}$} & \multicolumn{3}{|c|}{ Land equivalent ratio (LER) } & \multirow{2}{*}{ ATER } & \multicolumn{3}{|c|}{ Total economic } \\
\hline & & $\mathrm{L}_{\mathrm{a}}$ & $\mathrm{L}_{\mathrm{b}}$ & LER & & Sugar beet & Sunflower & Total \\
\hline \multirow{4}{*}{$\begin{array}{l}\text { Sugar beet }+ \\
100 \% \text { Sunflower }\end{array}$} & Zero & 0.42 & 0.93 & 1.36 & 0.91 & 3303.0 & 3104.8 & 6407.8 \\
\hline & 25 & 0.52 & 0.86 & 1.38 & 0.97 & 4094.7 & 2888.9 & 6983.6 \\
\hline & 50 & 0.71 & 0.79 & 1.50 & 1.13 & 5590.2 & 2654.7 & 8244.9 \\
\hline & 75 & 0.77 & 0.72 & 1.48 & 1.15 & 6060.4 & 2402.1 & 8462.5 \\
\hline \multirow{4}{*}{$\begin{array}{l}\text { Sugar beet }+ \\
80 \% \text { Sunflower }\end{array}$} & Zero & 0.48 & 0.77 & 1.25 & 0.89 & 3830.8 & 2566.2 & 6397.0 \\
\hline & 25 & 0.60 & 0.74 & 1.33 & 0.99 & 4706.7 & 2470.9 & 7177.6 \\
\hline & 50 & 0.79 & 0.72 & 1.51 & 1.17 & 6326.8 & 2402.6 & 8729.4 \\
\hline & 75 & 0.82 & 0.65 & 1.47 & 1.16 & 6443.8 & 2179.4 & 8623.2 \\
\hline \multirow{4}{*}{$\begin{array}{l}\text { Sugar beet }+ \\
67 \% \text { Sunflower }\end{array}$} & Zero & 0.51 & 0.72 & 1.22 & 0.88 & 4002.1 & 2397.5 & 6399.6 \\
\hline & 25 & 0.63 & 0.67 & 1.30 & 0.98 & 4970.3 & 2253.6 & 7223.9 \\
\hline & 50 & 0.79 & 0.67 & 1.46 & 1.14 & 6236.9 & 2234.4 & 8471.3 \\
\hline & 75 & 0.84 & 0.63 & 1.48 & 1.16 & 6627.6 & 2093.7 & 8721.3 \\
\hline Solid sugar beet & & 1 & --- & 1 & 1 & 7911.0 & --- & 7911.0 \\
\hline Solid sunflower & & --- & 1 & 1 & 1 & --- & 3344.0 & 3344.0 \\
\hline
\end{tabular}

L.E 263 ton $^{-1}$ of fresh sugar beet roots and, L.E 2750 ton $^{-1}$ of sunflower, $\left(\right.$ Feddan $\left.=4200 \mathrm{~m}^{2}\right)$.

\section{References}

Abbaspour F., M.R. Shakiba, H. Alyari and M. Valizade (2001). Effects of defoliation on yield and yield components of sunflower. Agric. Sci 12(4): 71-77.

Abd El-All, A.M. (2002). Weed control treatments for different intercropped systems of sugar beet and faba bean. J. Agric. Sci. Mansoura Univ., 27 (12): 8081-8092.

Agriculture Statistics (2010). Winter Crops. Agriculture Statistics and Economic Sector, 1st Ed., Ministry of Agriculture and Land Reclamation, Egypt.

Agriculture Statistics (2011). Summer \& Nili Crops. Agriculture Statistics and Economic Sector, 2nd Ed., Ministry of Agriculture and Land Reclamation, Egypt.

Beg, A., M. Pala and S.S. Poudad (2003). Sunflower Production as Influenced by Plant Density and Row Spacing on Dry Land. Proceeding of International Dry Land Conference held at Tehran Iran. September 2003.

Beshay, T. S. Maria, G. El-Ammaria, S. M. Allam, E. A. Neamat Alla and A. A. Abaziad. (2000). Productivity and monetary advantage of intercropping sugar beet with other winter crops .Egypt. J. Appl. Sci., 15 (9): 54-65.

Chapman, H.D. and Pratt, P.E. (1961). Methods of Analysis for Soil, Plant and Water. Division Agric. Sci., California Univ., U.S.A.
El Yamani Kh. M., T. Ibrahim Sahar and E.B.A. Osman (2010). Intercropping sunflower with soybean in the new valley. Egypt. J. of apll. Sci., 25:288.-302.

Hiebsch, C.K. (1980). Principles of intercropping. "Effect of $\mathrm{N}$ fertilization and crop duration on equivalency ratios in intercrops versus monoculture comparisons." PhD. Thesis. North Carolina State University, Raleigh, N. C., USA.

Jackson, M.L. (1958). Soil Chemical Analysis. Prentice Hall, Englwood Cliffis, New Jersy.USA.

Le- Docte, A. (1927). Commercial determination of sugar in beet root using the Sach. - Le Docte Proceses Int. Sug, J., 29: 488-492 (C.F Sugar beet Nutrition, 1972 Appl. Scr. Pub., London, A.P. Drycott).

Mohammed, Kh. Wafaa, A.El-M. El- Metwally, and S.A. Saleh (2005). Intercropping faba bean at different plant densities with sugar beet. Egypt, J. Agric. Res., 83: 649-662.

Mohammed, Kh. Wafaa, (2006). Sunflower and cucumber as affected by intercropping and some defoliation treatments of sunflower. Annals of Agric. Sc., Moshtohr, 44: 59-74.

Moriondo, M. O. and S. Bellesi. (2002). Effect of defoliation on growth of sunflower. Rivista- diAgron. 36: 197-201.

MSTATC (1980). A Microcomputer Program of the Design Management and Analysis of Agronomic Research Experiments. Michigan State Univ., USA. 
Muro, J., F.M. Ana and L. Carmen (2001). Defoliation effect on sunflower yields reduction. Agron. J., 93: 634-637.

Nagangoud, A. K. and M.D.S. Yelshetty (1996). Effects of time and degree of defoliation on sunflower yield. J. Maharashtra-Agric. Univ. 21: 151-152; ref.

Olanite J.A, B.A.O. Ibikunle, and A.O. Jolaosho (2002). Effect of intercropping on the yield and yield components of maize and sunflower in the southern guinea savanna zone of Nigeria. Moor-J. Agric. Res. 3: 169-174.

Osman, E.B.A. and M.M.M. Awed (2010). Response of sunflower (HELIANTHUS ANNUUS L.) to phosphorus and nitrogen fertilizer under different plant spacing at new valley. Ass. Univ. Bull. Environ. Res. 13: 11-19.

Patil D.H; B.T. Pujari, S.S. Prakash and H.T. Chandranath (2007). Nutrient uptake by groundnut and sunflower in intercropping system. Agricultural Research Information Centre , Hissar, India.

Sahoo, S.K., D.S. Kumar and C.R. Reddy (2003). Productivity of sunflower (Helianthus annuus L.) based intercropping systems under rabi irrigated conditions. Dep. Agron. S.V. Agric. College, ANGRAU, Tirupati - India, 517502.

Snedecor, G.W. and W.G. Cochran (1988). Statistical Methods. 7th Ed. Iowa State Univ. Press, Ames, Iowa, USA.

Toaima, S.E.A.1, K.A., El-Douby and A.I. Nafei (2001). Effect of different intercropping systems of onion and garlic on sugar beet yield components and chemical analysis. Egyptian J. Agric .Res., 79(3):983-1004.

Verma S.S., Y.P., Joshi and S.C., Saxena (2005). Effect of row ratio of fodder sorghum (Sorghum bicolor) in pigeonpea (Cajanus cajan) intercropping system on productivity, competition functions and economics under rainfed conditions of north India. Indian $\mathrm{J}$. of Agron. 50: 123-125.

Vishwanatha S, B.G. Koppalkar, S.N. Anilkumar, B.K. Desai and Vinayak Naik. (2011). Economics and Yield Advantages of Pigeonpea and Sunflower Intercropping System Influenced by Fertilizer Management. Res. Jour. of Agric. Sci., 2(2): 248-251.

Willey, R.W. (1979). Intercropping: its importance and research needs. Part 1.Competition and yield advantage. (c.f. Field Crops Abst. 32, 1-10). 


\title{
تأثير تحميل زهرة الشمس مع بنجر السكر تحت معاملات كثافات نباتية وتوريق مختلفة على المحصول وكفاءة الانتاج الكلى للمحصولين
}

\author{
وفاء خميس محمد و شعبان رمضان عبد الظاهر \\ قسم بحوث التكثيف المحصولى - معهل المحاصيل الحقلية- \\ مركز البحوث الزراعية - جيزة - مصر
}

أجريت تجربتان حقليتان خلال الموسمين الثتوبين 2010/2009 و 2011/2010 في محطة البحوث والتجارب الزراعية - مركز

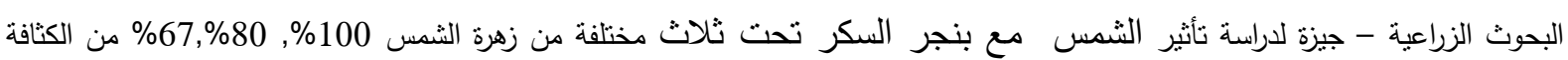
النباتية الموصى بها (35 ألف نبات/ فدان) وأربعة مستويات من النوريق لنبات لزهرة الثمس عند مرحلة الطور اللبني (75، 50، 25 \% وبدون

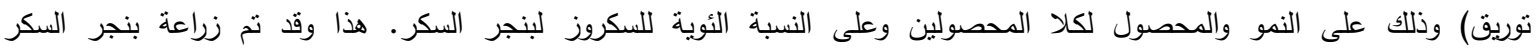

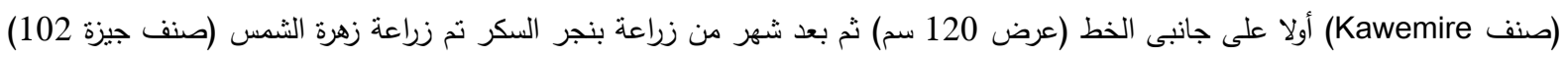

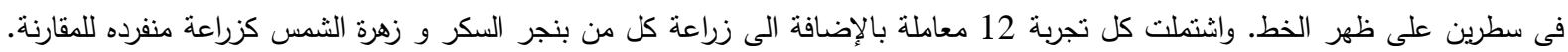

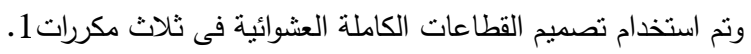
ويمكن ايجاز اهم النتائج المتحصل عليها كالثالي: -

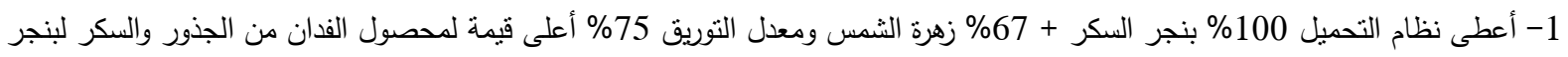
السكر في الموسمين في حين أعطي تحميل 100\% بنجر السكر + 100\% زهرة الثمس بدون توريق أقل قيمة وذلك مقارنة بمحصول بنجر السكر المنفرد لموسمي الزراعة. 2- أظهرت النتائج الدتحصل عليها أن نظام التحميل 100\% بنجر السكر + 100\% زهرة الثمس بدون توريق أعطى أعلى قيمة لمحصول

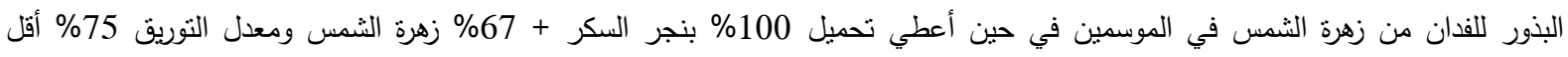
محصول مقارنة بمحصول زهزة الثنس المنفرد خلال موسمي الزراعة.

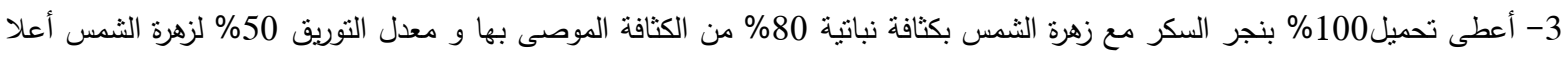

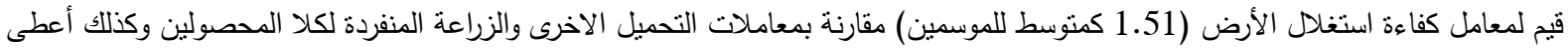

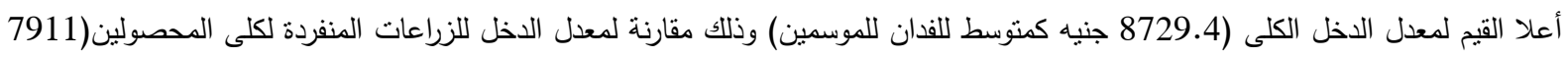
جنيه كمنوسط لفدان بنجر السكر , 3344 جنيه كمنوسط لفدان زهرة الثمس). 